\title{
Toxicon
}

Toxicon 48 (2006) 323-330

www.elsevier.com/locate/toxicon

\section{Accumulation and depuration profiles of PSP toxins in the short-necked clam Tapes japonica fed with the toxic dinoflagellate Alexandrium catenella}

\author{
Mohamad Samsur ${ }^{\mathrm{a}}$, Yasunaga Yamaguchi ${ }^{\mathrm{b}}$, Takefumi Sagara ${ }^{\mathrm{c}}$, \\ Tomohiro Takatani ${ }^{\mathrm{d}}$, Osamu Arakawa ${ }^{\mathrm{d}, *}$, Tamao Noguchi ${ }^{\mathrm{e}}$ \\ ${ }^{a}$ Graduate School of Science and Technology, Nagasaki University, Nagasaki 852-8521, Japan \\ ${ }^{\mathrm{b}}$ Maruzen Pharmaceuticals Corporation Ltd., Hiroshima 729-3102, Japan \\ ${ }^{\mathrm{c}}$ Shikoku University Junior College, Tokushima 771-1192, Japan \\ ${ }^{\mathrm{d}}$ Faculty of Fisheries, Nagasaki University, Nagasaki 852-8521, Japan \\ ${ }^{\mathrm{e}}$ Tokyo Health Care University, Tokyo 154-8568, Japan
}

Received 25 January 2006; accepted 1 June 2006

Available online 27 June 2006

\begin{abstract}
A toxic dinoflagellate responsible for paralytic shellfish poisoning (PSP), Alexandrium catenella (Ac) was fed to the short-necked clam Tapes japonica, and the accumulation and depuration profiles of PSP toxins were investigated by means of high-performance liquid chromatography with postcolumn fluorescence derivatization (HPLC-FLD). The short-necked clams ingested more than $99 \%$ of the $A c$ cells $\left(4 \times 10^{7}\right.$ cells) supplied once at the beginning of experiment, and accumulated a maximal amount of toxin $(185 \mathrm{nmol} / 10$ clams $)$ after $12 \mathrm{~h}$. The rate of toxin accumulation at that time was $23 \%$, which rapidly decreased thereafter. Composition of the PSP toxin accumulated in the clams obviously different from that of $A c$ even $0.5 \mathrm{~h}$ after the cell supply, the proportion of $\mathrm{Cl}+2$ being much higher than in $A c$, although the reason remains to be elucidated. In contrast, a higher ratio of gonyautoxin (GTX) $1+4$ than in $A c$ was detected in the toxin profiles of clam excrements. The variation in toxin composition derived presumably from the transformation of toxin analogues in clams was observed from $0.5 \mathrm{~h}$, such as reversal of the ratio of $\mathrm{C} 1$ to $\mathrm{C} 2$, and appearance of carbamate (saxitoxin (STX), neoSTX and GTX2, 3) and decarbamoyl (dc) derivatives (dcSTX and dcGTX2, 3), which were undetectable in $A c$ cells. The total amount of toxin distributed over $A c$ cells, clams and their excrements gradually declined, and only $1 \%$ of supplied toxin was detected at the end of experiment.
\end{abstract}

(C) 2006 Elsevier Ltd. All rights reserved.

Keywords: Tapes japonica; Alexandrium catenella; Paralytic shellfish poisoning (PSP); Toxin accumulation

\section{Introduction}

Intoxication of filter-feeding bivalves during blooms of toxic dinoflagellates responsible for

*Corresponding author. Fax: +81958192844.

E-mail address: arakawa@nagasaki-u.ac.jp (O. Arakawa). paralytic shellfish poisoning (PSP) has become a global concern in recent decades (Hallegraeff, 1993). PSP toxins produced by dinoflagellates can be concentrated and retained in bivalve tissues, and pose a significant human health risk after consumption of the contaminated bivalves (Bricelj and Shumway, 1998). Every year, along the coastal 